\title{
FTIR STUDY OF TWO DIFFERENT LIGNITE LITHOTYPES FROM NEOCENE ACHLADA LIGNITE DEPOSITS IN NW GREECE
}

\author{
Oikonomopoulos I. ${ }^{1}$, Perraki Th. ${ }^{1}$, and Tougiannidis N. ${ }^{2}$ \\ ${ }^{1}$ National Technical University of Athens, School of Mining \& Metallurgical Engineering, Division of Geo- \\ sciences, 9 Heroon Politechniou St., GR-15773Zzografou,Greece.giannis@metal.ntua.gr, \\ peraki@metal.ntua.gr \\ ${ }^{2}$ Institute of Geology and Mineralogy, University of Cologne.GeoNikolas@gmx.de
}

\begin{abstract}
The FTIR spectra for both Neogene xylite and matrix lignite samples from Achlada NW Greece show significant differences, which are mainly evident in aliphatic stretching region (3000-2800 $\left.\mathrm{cm}^{-1}\right)$ where the intensities of the vibrations are reduced in matrix lignite lithotype compared to xylite one. The intense bands in the region 3402-3416 $\mathrm{cm}^{-1}$ are attributed to - $\mathrm{OH}$ stretching of $\mathrm{H}_{2} \mathrm{O}$ and phenol groups. The bands at $\sim 3697 \mathrm{~cm}^{-1}$ and $\sim 3623 \mathrm{~cm}^{-1}$ as well as at $\sim 538 \mathrm{~cm}^{-1}$ and $470 \mathrm{~cm}^{-1}$, which are more evident in the FTIR spectra of matrix lignite, are attributed to higher content of clay minerals in the samples of this lithotype. The stretching vibration appears at $1032 \mathrm{~cm}^{-1}$ is intense in all matrix lignite samples and it is broadening in the xylite ones. The FTIR spectra of all samples confirm the progressive elimination of aliphatic vibrations from xylite lithotype to matrix lignite one and the appearance of clay minerals in the latter. As a whole the FTIR spectra of both xylite and matrix lignite confirm the significant differences between these two lignite lithotypes.
\end{abstract}

Key words: FTIR, Neocene, lignite, xylite, Achlada, Greece.

\section{Introduction}

At the end of diagenesis the polycondensed organic residue, called lignite in coal swamps, also contains varying amounts of largely unaltered refractory organic material (Killops and Killops, 1993). Therefore, the organic structure of coal can be regarded as consisting of heterogeneous aromatic structures, with aromaticity increasing from low rank (lignite, brown coal) to high rank coals (semianthracite, anthracite). The term lignite refers to the maturity stage of coals, while the terms xylite and matrix refer to lignite lithotype. Fourier Transform Infra Red (FT-IR) method is a widely used analytical technique for determining the different functional groups of coal structures. Infrared (IR) spectroscopy has been extensively employed in the characterization of the mineral and organic matter of coals (Guiliano et al., 1990; Cloke et al., 1997; D’ Alessio et al., 2000; Georgakopoulos et al., 2003; Kalaitzidis, 2007; e.t.c).

In Greek lignites a limited number of studies have been published up to now, using FTIR method for coal characterization. Georgakopoulos et al. (2003) resulted in the presence of phenolic and alcocholic C-O bonds as well as C-O-C bonds with aliphatic carbons (strong peak at $1032 \mathrm{~cm}^{-1}$ ) concerning the initial xylite sample BEX from Vevi region. In the same study the FT-IR spectra of lignite and humic clay samples, from Apofysis-Amynteo lignite deposits NW Greece, revealed the great 


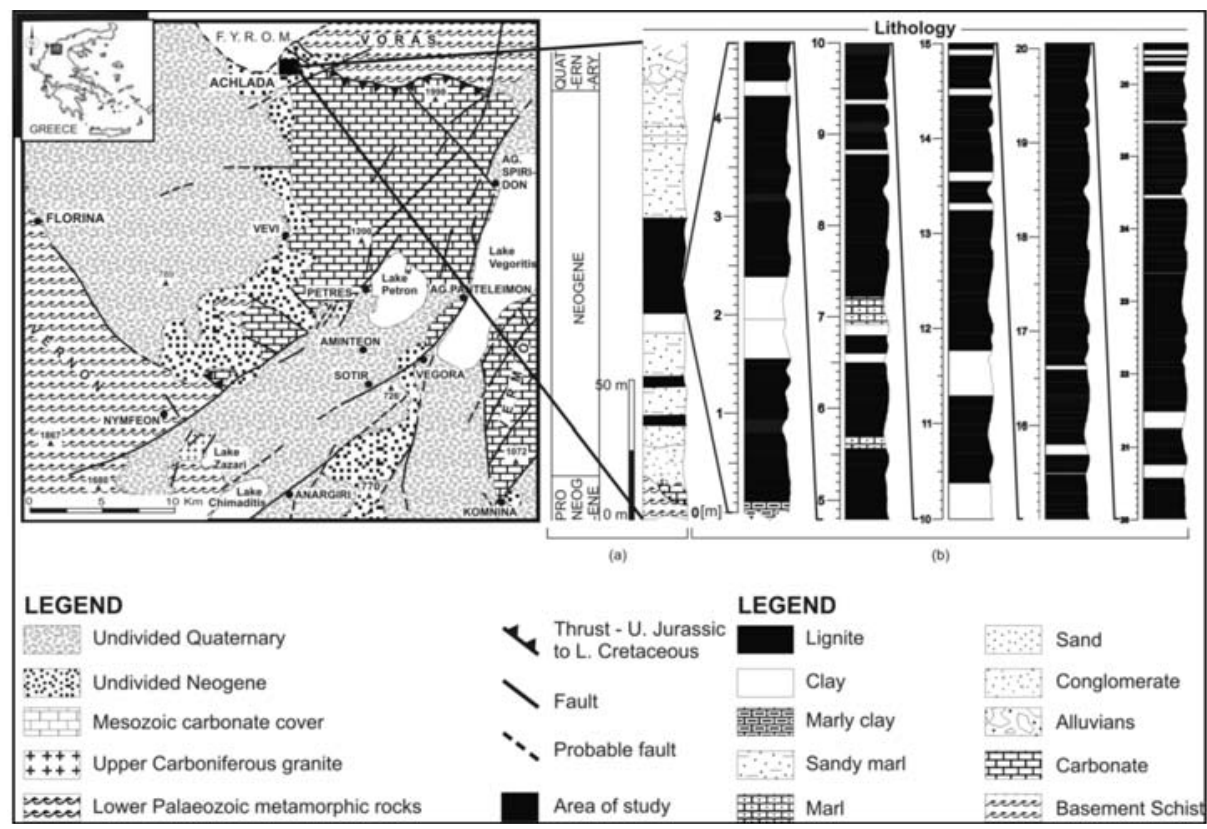

Fig. 1: Geological map of the Florina Basin with the location and generalized lithological column (a) of the studied area (after Pavlides \& Mountrakis 1987) and (b) of Achlada lignite deposits, NW Greece.

abundance of $\mathrm{C}=\mathrm{O}$ and $\mathrm{C}-\mathrm{O}-\mathrm{R}$ structures $\left(1800-1000 \mathrm{~cm}^{-1}\right.$ region) as well as clay and silicate minerals in the $3600-3800 \mathrm{~cm}^{-1}$ and $400-600 \mathrm{~cm}^{-1}$ region, respectively.

No study has been published concerning the investigation by FTIR method of the organic beds of Achlada lignite deposits, Florina sub-basin, NW Greece.

The present study is part of a research of both xylite and matrix lignite aimed at their structural characterization by Fourier transform infrared spectroscopy (FTIR) and focuses on their significant differences. X-ray diffraction (XRD), thermo-gravimetric (TG/DTG) and differential thermal analysis (DTA) were also employed for this purpose.

\section{Geological setting}

The studied samples obtained from the lignite-bearing sequence of Neocene Achlada lignite deposits, which are located at the east margins of Florina sub-basin, NW Grecce.

The Neocene-Quaternary sediments that fill the basin, overlay unconformably both Palaeozoic metamorphic rocks and Mesozoic crystalline limestones and consist of conglomerates, sands, marls, sandy marls, clays, lignite beds, lateral fans and alluvial deposits (Pavlides and Mountrakis, 1987).

\section{Methods}

Lithological features of each of the studied samples were macroscopically described and the lignite lithotype determined according to guidelines established by the International Committee for Coal and Organic Petrology (I.C.C.P., 1993), as well as by Taylor et al. (1998). Samples with less than 10\% by volume woody tissues were logged as matrix lignite, whereas those of immiscibly woody tissues were classed as xylite. 
Several xylite and matrix lignite samples were examined using the FTIR method of analysis. The IR measurements were carried out using a Fourier Transform Infra Red (FT-IR) spectrophotometer (Perkin Elmer GX-1). The FT-IR spectra, in the wavenumber range from $4000 \mathrm{~cm}^{-1}$ to $400 \mathrm{~cm}^{-1}$, were obtained using the $\mathrm{KBr}$ pellet technique. The pellets were prepared by pressing a mixture of the sample and of dried $\mathrm{KBr}$ (sample:KBr, approximately 1:200), at 8 tons $/ \mathrm{cm}^{2}$. Bands were identified by comparison to published studies (Wang and Griffith, 1985; Lide, 1991; Sobkowiak and Painter, 1992; Van Krevelen, 1993; Mastalerz and Bustin, 1995, 1996; Ibarra et al., 1996; Cloke et al., 1997; Koch et al., 1998; Das, 2001; e.c.t). Bands assignments used in this paper are listed in table 1.

Peak areas representing the hydroxyl group region (3100-3700 $\left.\mathrm{cm}^{-1}\right)$, aliphatic stretching region (2931-2855 $\mathrm{cm}^{-1}$ ), aromatic carbon (peaks at 1618 and $1606 \mathrm{~cm}^{-1}$ ), aliphatic bending region (1509$\left.1371 \mathrm{~cm}^{-1}\right)$, cellulose and lignin region $\left(1300-1000 \mathrm{~cm}^{-1}\right)$ and the aromatic out-of-plane region (900$700 \mathrm{~cm}^{-1}$ ) were measured. Additionally, intense vibrations at $3698 \mathrm{~cm}^{-1}, 3620 \mathrm{~cm}^{-1}, 531 \mathrm{~cm}^{-1}$ and $469 \mathrm{~cm}^{-1}$ are attributed to clay and silicate minerals.

The same xylite and matrix lignite samples were also examined by means of X-ray diffraction (XRD) analysis, as well as thermo-gravimetric (TG/DTG) and differential thermal (DTA) analysis. X-ray power diffraction patterns were obtained using a Bruker D-8 Focus diffractometer, with Ni-filtered CuK $\alpha_{1}$ radiation $(\lambda=1.5405 \AA)$, operating at $40 \mathrm{kV}, 30 \mathrm{~mA}$, while TG/DTG/DTA were obtained simultaneously using a thermal analyzer (Mettler, Toledo 851 ) at a heating rate of $10^{\circ} \mathrm{C} / \mathrm{min}$, at air atmosphere and temperature range $25^{\circ} \mathrm{C}-1200^{\circ} \mathrm{C}$.

\section{Results and Discussion}

\subsection{FTIR study of xylite and matrix lignite samples}

Representative FT-IR spectra of xylite and matrix lignite samples are shown in figure 2. The spectra differ significantly in the peaks due to mineral matter, as well as to phenolic $(\mathrm{C}-\mathrm{O})$ and aliphatic carbon (C-H) groups.

Both representative spectra show typical infrared characteristics of the organic matter of low-rank coals, including aliphatic $\mathrm{C}-\mathrm{H}$ stretching bands at $2924 \mathrm{~cm}^{-1}$ and $2856 \mathrm{~cm}^{-1}, \mathrm{C}=\mathrm{C}$ or $\mathrm{C}=\mathrm{O}$ aromatic ring stretching vibrations at $\sim 1610 \mathrm{~cm}^{-1}$ and at $\sim 1506 \mathrm{~cm}^{-1}$, as well as aliphatic $\mathrm{C}-\mathrm{H}$ stretching bands, at $1455 \mathrm{~cm}^{-1}, 1370 \mathrm{~cm}^{-1}$ and $822 \mathrm{~cm}^{-1}$.

Due to the fact that the present functional groups are different for xylite and matrix lignite samples it is more convenient to describe them separately.

Studying the FTIR spectra of the representative xylite sample (Fig. 2a), from the Achlada lignite deposits in NW Greece, the following conclusions resulted:

- The broad band at $3392 \mathrm{~cm}^{-1}$ is attributed to -OH stretching vibrations of hydrogen-bonded hydroxyl groups of absorbed water of clay minerals as well as to - $\mathrm{OH}$ of phenol groups.

- The strong peak at $2931 \mathrm{~cm}^{-1}$ is due to asymmetric aliphatic C-H stretching vibrations of methylene $\left(-\mathrm{CH}_{2}\right)$.

- The band at $\sim 1606 \mathrm{~cm}^{-1}$ is attributed either to $\mathrm{C}=\mathrm{O}$ or $\mathrm{C}=\mathrm{C}$ aromatic ring stretching vibrations.

- The band at $\sim 1505 \mathrm{~cm}^{-1}$ is due to $\mathrm{C}=\mathrm{O}$ stretching vibrations.

- The band at $\sim 1454 \mathrm{~cm}^{-1}$ is attributed to symmetric aliphatic $\mathrm{C}-\mathrm{H}$ vibration of methylene $\left(\mathrm{CH}_{2}\right)$ and methoxyl $\left(\mathrm{OCH}_{3}\right)$.

- The peak at $\sim 1370 \mathrm{~cm}^{-1}$ is due to symmetric aliphatic $\mathrm{C}-\mathrm{H}$ bending vibration of methyl groups $\left(\mathrm{OCH}_{3}\right)$.

- The band at $\sim 1265 \mathrm{~cm}^{-1}$ are attributed to $\mathrm{C}-\mathrm{O}$ stretching vibrations. 


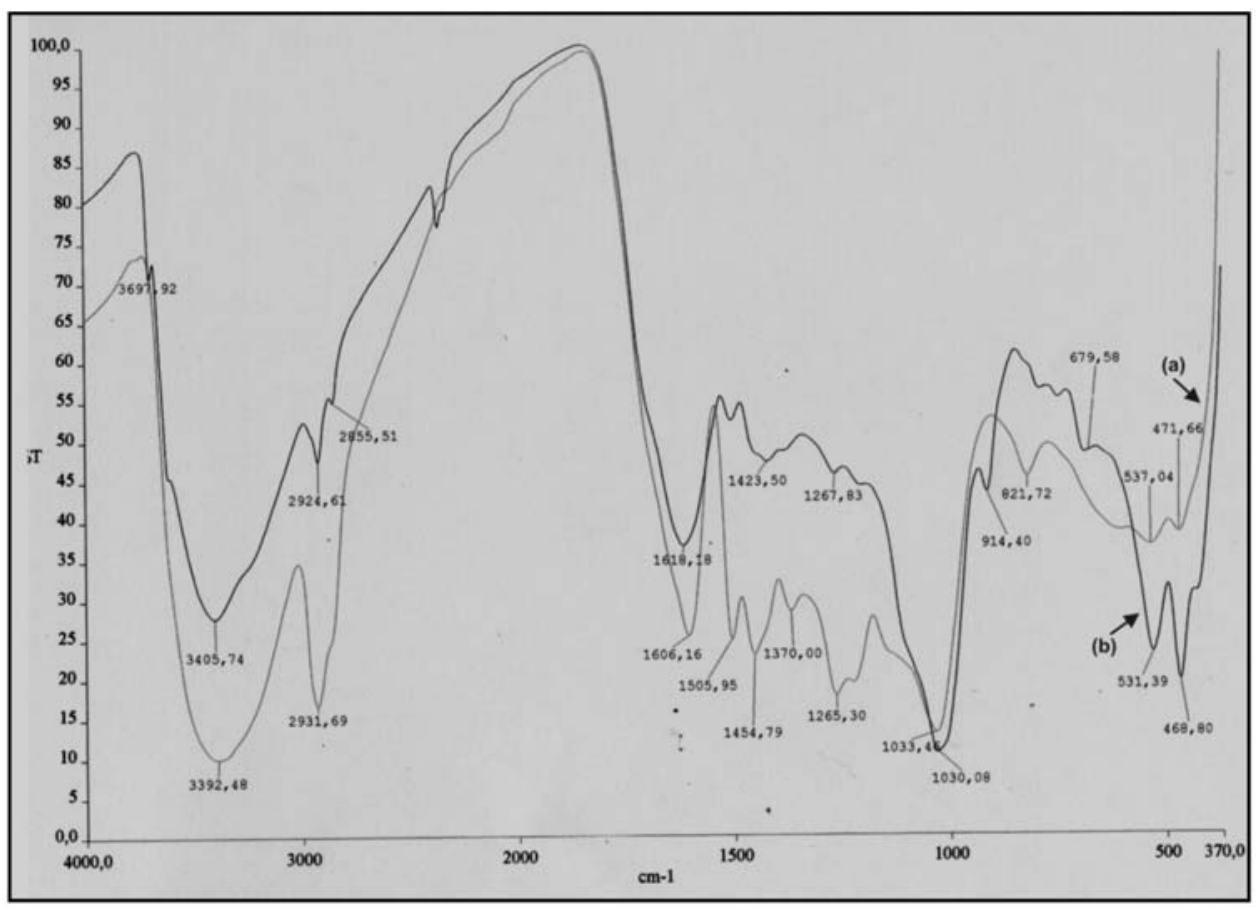

Fig. 2: FTIR spectra of representative xylite (a) and matrix lignite (b) samples.

- The peak at $\sim 1033 \mathrm{~cm}^{-1}$ is due to C-O-H bonds in cellulose as well as to C-O stretching vibrations of aliphatic ethers (R-O-Ŕ) and alcohols (R-OH).

- The band at $\sim 821 \mathrm{~cm}^{-1}$ is due to out-of-plane-aryl ring with isolated $\mathrm{C}-\mathrm{H}$ groups.

In the FT-IR spectra of the matrix lignite samples bands corresponding to the most abundant minerals were detected confirming the occurrence of clay minerals (e.g. kaolinite bands at $\sim 3698 \mathrm{~cm}^{-1}$, $3620 \mathrm{~cm}^{-1}, 1030 \mathrm{~cm}^{-1}, 915 \mathrm{~cm}^{-1}, 531 \mathrm{~cm}^{-1}$, and $469 \mathrm{~cm}^{-1}$ ). The small peaks at $3698 \mathrm{~cm}^{-1}$ and 3620 $\mathrm{cm}^{-1}$ can be assigned to the crystal water which exists in clay minerals of the matrix lignite samples (Geng et al., 2009).

Studying the FTIR spectra of the representative matrix lignite sample (Fig. 2b), from the Achlada lignite deposits in NW Greece, the following conclusions resulted:

- The small peak at $\sim 3698 \mathrm{~cm}^{-1}$ arises from the in-phase symmetric stretching vibration of the $\mathrm{OH}$ groups, either "outer" or "inner" surface $\mathrm{OH}$ of the octahedral sheets, which form week hydrogen bonds with the oxygen of the next tetrahedral layer (Balan et al., 2001). The peak at $3620 \mathrm{~cm}^{-1}$ is due to the stretching vibrations of the "inner $\mathrm{OH}$ groups" lying between the tetrahedral and octahedral sheets (Madejova, 2002; Geng et al., 2009).

- The broad band at $\sim 3406 \mathrm{~cm}^{-1}$ is attributed to -OH stretching vibration of absorbed water either of clay minerals or of the organic matter of the matrix lignite sample.

- The bands at $2925 \mathrm{~cm}^{-1}$ and $\sim 2855 \mathrm{~cm}^{-1}$ are attributed to asymmetric and symmetric aliphatic $-\mathrm{CH}_{2}$ stretching vibrations respectively.

- The strong band at $\sim 1618 \mathrm{~cm}^{-1}$ is attributed either to $\mathrm{C}=\mathrm{O}$ or $\mathrm{C}=\mathrm{C}$ aromatic ring stretching vibrations, as well as to $\mathrm{OH}$ bending vibrations of adsorbed water. 
Table 1. Characteristic FTIR bands of functional groups of low rank coals.

\begin{tabular}{|c|l|}
\hline $\begin{array}{c}\text { Wavenumber } \\
\left(\text { cm }^{-1}\right)\end{array}$ & \multicolumn{1}{c|}{ Assignment } \\
\hline 3400 & $\begin{array}{l}\text { O-H stretching vibrations of hydrogen-bonded hydroxyl groups in } \\
\text { polymeric association }\end{array}$ \\
\hline 2930 & Asymmetric aliphatic C-H stretch vibrations-methylene $(\mathrm{CH} 2)$ \\
\hline 2850 & Symmetric aliphatic C-H stretch vibrations-methylene $(\mathrm{CH} 2)$ \\
\hline 1610 & Aromatic ring (C=C in plane) stretching symmetric \\
\hline 1510 & C=O stretching vibrations \\
\hline 1458 & Asymmetric aliphatic C-H deformation of methylene and methoxyl \\
\hline $1430-1420$ & aromatic C=C stretching vibrations \\
\hline 1370 & Symmetric aliphatic C-H bending of methyl groups CH3 \\
\hline 1266 & C-O stretch vibration (in lignin-gualacyl ring with C-O stretch) \\
\hline 1224 & C-O stretch vibration (in lignin-gualacyl ring and C-O stretch) \\
\hline 1031 & C-O-H deformation in cellulose \\
\hline 822 & Aromatic out-of-plane-rings with 2 neighboring C-H groups \\
\hline$\sim 534$ & Si-O-Al ${ }^{\mathrm{VI}}$ vibrations (Al in octahedral co-ordination) of clay minerals \\
\hline$\sim 468$ & Si-O-Si bending vibrations of clay minerals \\
\hline
\end{tabular}

- The $\sim 1030 \mathrm{~cm}^{-1}$ and $1013 \mathrm{~cm}^{-1}$ bands arise from the Si-O-Si and Si-O-Al ${ }^{\mathrm{VI}}$ vibrations, respectively.

- The $\sim 914 \mathrm{~cm}^{-1}$ band arises from the bending vibrations of "inner" $\mathrm{OH}$ groups of $\mathrm{Al}-\mathrm{OH}-\mathrm{Al}$ of kaolinite structure.

- The band at $\sim 680 \mathrm{~cm}^{-1}$ could be related to aromatic out-of-plane $\mathrm{C}-\mathrm{H}$ vibrations, rather than to mineral matter (Georgakopoulos, 2003).

- The band at $\sim 531 \mathrm{~cm}^{-1}$ originates from Si-O-Al ${ }^{\mathrm{VI}}$ vibrations ( $\mathrm{Al}$ in octahedral co-ordination), while the band at $\sim 469 \mathrm{~cm}^{-1}$ is attributed to the Si-O-Si bending vibrations (Van Jaarsveld et al., 2002; Madejova, 2003).

The main FTIR absorption bands of both xylite and matrix lignite samples are summarized in table 1 .

The comparative FT-IR spectroscopy of xylite and matrix lignite lithotypes showed that:

- An intense and broad hydroxyl band of the xylite sample with a maximum at $\sim 3392 \mathrm{~cm}^{-1}$, was displaced relatively to the matrix lignite band which appears at $\sim 3406 \mathrm{~cm}^{-1}$. The latter peak is accompanied by two other small peaks around $3698 \mathrm{~cm}^{-1}$ and $3620 \mathrm{~cm}^{-1}$ due to mineral matter, which is more abundant in the matrix lignite.

- The predominant FTIR feature for xylite samples (Fig. 2b), in contrast to matrix lignite ones, is the high intensity of aliphatic C-H stretching vibration at $\sim 2931 \mathrm{~cm}^{-1}$, which appears at slightly lower wavenumbers (2925 and $\left.2856 \mathrm{~cm}^{-1}\right)$, in matrix lignite samples.

Significant differences of the containing functional groups are also present in the $1700-1100 \mathrm{~cm}^{-1} \mathrm{re}-$ gion. More specifically:

- The stretching vibrations at $\sim 1506 \mathrm{~cm}^{-1}$ due to $\mathrm{C}=\mathrm{O}$ structures tend to decrease in matrix lignite. As far as, the bands at this region $\left(\sim 1506 \mathrm{~cm}^{-1}\right)$ practically disappear at the stage of bi- 

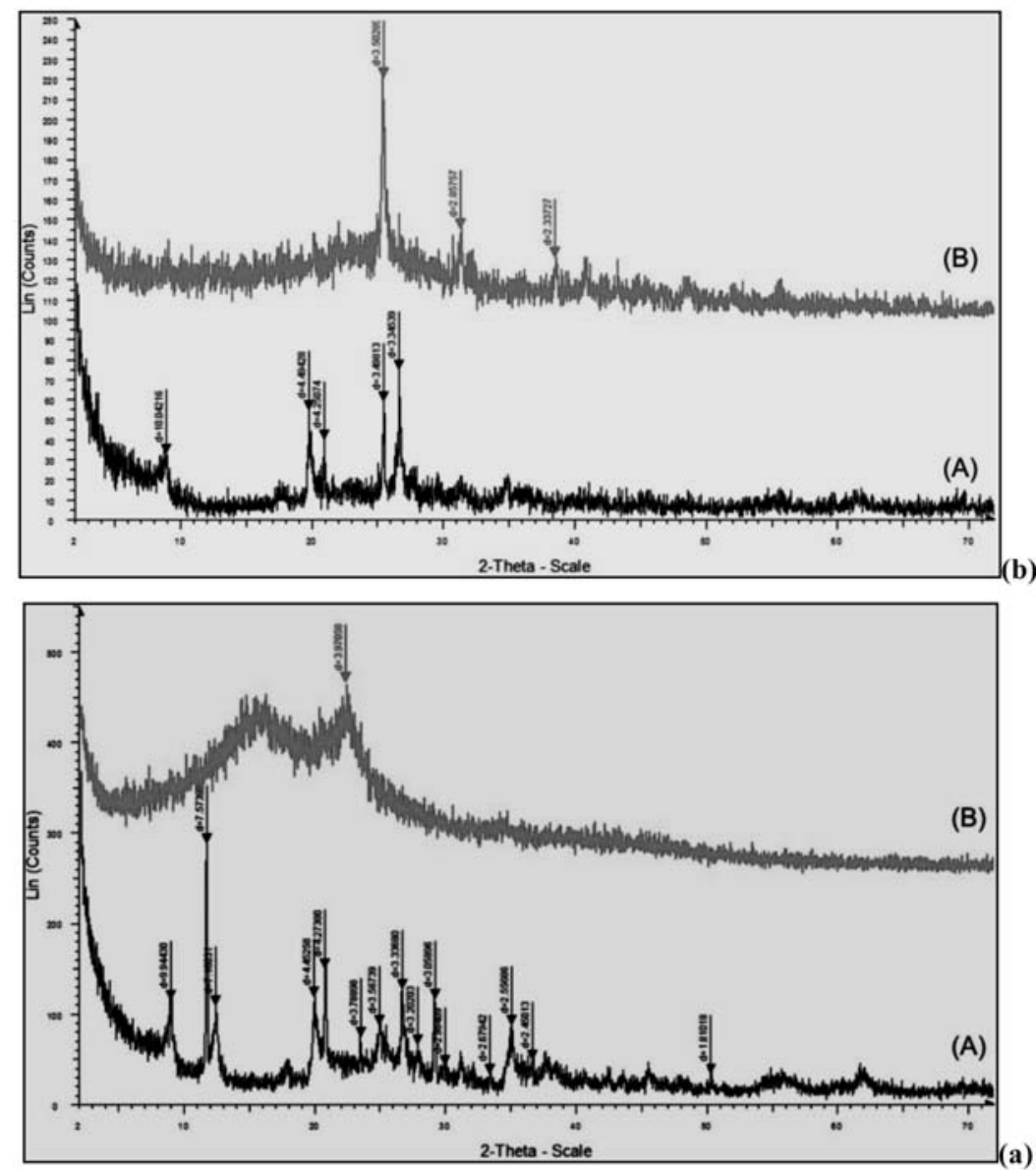

Fig. 3: X-ray diffraction diagrams of representative matrix lignite (A) and xylite (B) samples, before (a) and after (b) heating up to $550^{\circ} \mathrm{C}$.

tuminous coal (Ibarra et al., 1996), the progressive elimination of stretching vibrations in this region probably indicates increasing coalification from xylite to matrix lignite lithotype.

- The vibrations due to the aliphatic C-H and C-O groups at $\sim 1455 \mathrm{~cm}^{-1}, 1370 \mathrm{~cm}^{-1}, 1265 \mathrm{~cm}^{-}$ ${ }^{1}$ and $1224 \mathrm{~cm}^{-1}$, as well as the out of plane vibration due to the $\mathrm{C}-\mathrm{H}$ bonds at $823 \mathrm{~cm}^{-1}$ also decrease in matrix lignite (Ibarra et al., 1996).

- Strong vibrations corresponding to the occurrence of clay minerals (e.g. kaolinite bands at $\sim 3698$ $\mathrm{cm}^{-1}, 3620 \mathrm{~cm}^{-1}, 1031 \mathrm{~cm}^{-1}, 915 \mathrm{~cm}^{-1}, 531 \mathrm{~cm}^{-1}$, and $469 \mathrm{~cm}^{-1}$ ) were detected in the FT-IR spectra of the matrix lignite samples, while for the xylite ones a limited number of these vibrations are present, which are also quite weak.

- The prominent band at $\sim 680 \mathrm{~cm}^{-1}$ in matrix lignite sample, could be related to aromatic outof-plane C-H deformations, rather than to mineral matter (Georgakopoulos, 2003).

\subsection{X-ray diffraction (XRD) analysis of xylite and matrix lignite samples}

The X-ray diffraction (XRD) analysis revealed that the minerals present in matrix lignite are mainly, 
kaolinite and gypsum (Fig. 3aA), while anhydrite is present in both heated samples (Fig. 3bA,B). Illite (+muscovite) is identified by the sharp diffraction peaks at $\mathrm{d}_{001}=\sim 10 \AA$ and $\mathrm{d}_{003}=\sim 3.34 \AA$, while kaolinite by its typical peaks at $\mathrm{d}_{001}=\sim 7.1 \AA$ and $\mathrm{d}_{002}=\sim 3.5 \AA$. In the same figure gypsum is identified by its characteristic peak at $\mathrm{d}_{020}=\sim 7.56 \AA$. Minerals in minor contribution such as quartz at $\mathrm{d}_{101}=3.34 \AA$ and $\mathrm{d}_{100}=4.26 \AA$ and calcite at $\mathrm{d}_{104}=\sim 3.03 \AA$ have been detected, too. It is important to be mentioned that the formation of anhydrite, in the heated samples at $\mathrm{d}_{020}=\sim 3.49 \AA$ and $\mathrm{d}_{210}=\sim 2.85$ $\AA$ indicates the presence of gypsum in raw materials.

From the X-ray diagrams (Fig. 3a) it becomes clear that clay minerals are present in the matrix lithotype, while in the xylite one these are absent. This observation confirms the FTIR results, in which the typical bands of clay minerals are absent from xylite spectrum. This may be attributed to the nature of xylite samples that prevent the water movement through the xylite mass.

In addition, the samples were heated up to $550^{\circ} \mathrm{C}$ for 2 hours, in a static oven (Fig. 3b). Samples were then cooled at room temperature and examined by X-ray power diffraction (XRD). A decrease in the intensity of the characteristic diffraction pattern at $d=\sim 7.57 \AA$, due to the collapse of gypsum, as well as the presence of typical peaks at $d=\sim 3.50 \AA$ and $d=\sim 2.85 \AA$ (Fig. 3b), indicates clearly the presence of anhydrite for both xylite and matrix lignite lithotypes.

\subsection{TG/DTG and DTA study of xylite and matrix lignite samples}

The thermal study results of the Achlada low rank coal samples examined after heating up to $1200^{\circ} \mathrm{C}$, at a rate of $10^{\circ} \mathrm{C} / \mathrm{min}$, are shown in Fig. 4a,b. The TG curves of the examined samples showed a continuous weight loss during heating up to $\sim 650^{\circ} \mathrm{C}$ and $900^{\circ} \mathrm{C}$, for xylite and matrix lignite samples, respectively. More specifically:

- The steep slope of the xylite TG curve, in the temperature range from $200^{\circ} \mathrm{C}$ to $500^{\circ} \mathrm{C}$, due to the rapid weight loss is attributed to the high devolatilization rate of organic matter.

- In the same temperature range, a big and sharp devolatilization peak observed at the DTG curve indicates the high devolatilization rate of xylite lithotype comparing to matrix one. This sharp peak at $\sim 380^{\circ} \mathrm{C}$ (Fig. 4a) can be attributed to cellulose content of xylite sample (Charland et al., 2003). Taking into consideration that this peak height can provide a relative measure of the reactivity, the xylite seemed to be more reactive, as far as its decomposition rates were higher than those corresponding to the matrix lignite (Vamvuka et al., 2004). On the other hand, the bulk of the burning process for matrix lignite occurred mainly between $450^{\circ} \mathrm{C}$ and $600^{\circ} \mathrm{C}$.

- An endothermic peak at $\sim 380^{\circ} \mathrm{C}$ (DTA curve) is associated with the decomposition of cellulose, while the decomposition of lignin is characterized by an exothermic one, in the temperature range from $200^{\circ} \mathrm{C}$ to $400^{\circ} \mathrm{C}$ (Fig. 4a).

-Xylite samples present higher weight loss up to $1000^{\circ} \mathrm{C}(67.35 \% \mathrm{wt})$, comparing to matrix lignite ones $(37.66 \% \mathrm{wt})$. The water that is evolved during pyrolysis arises from $\mathrm{OH}$ of constituent water as well as from the condensation of phenols (MacPhee et al., 2004), as it is shown in the following equation:

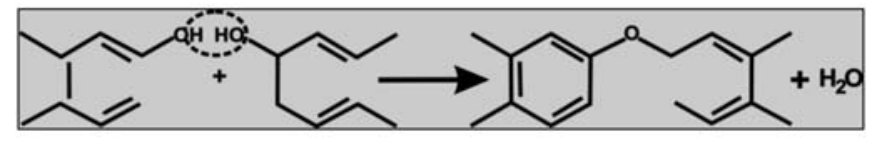

The thermogravimetric curves of the Achlada low rank coal samples examined show that:

- The first peak of DTG curve at $100^{\circ} \mathrm{C}$, which is associated with sample drying phase (Fig. 4b). 

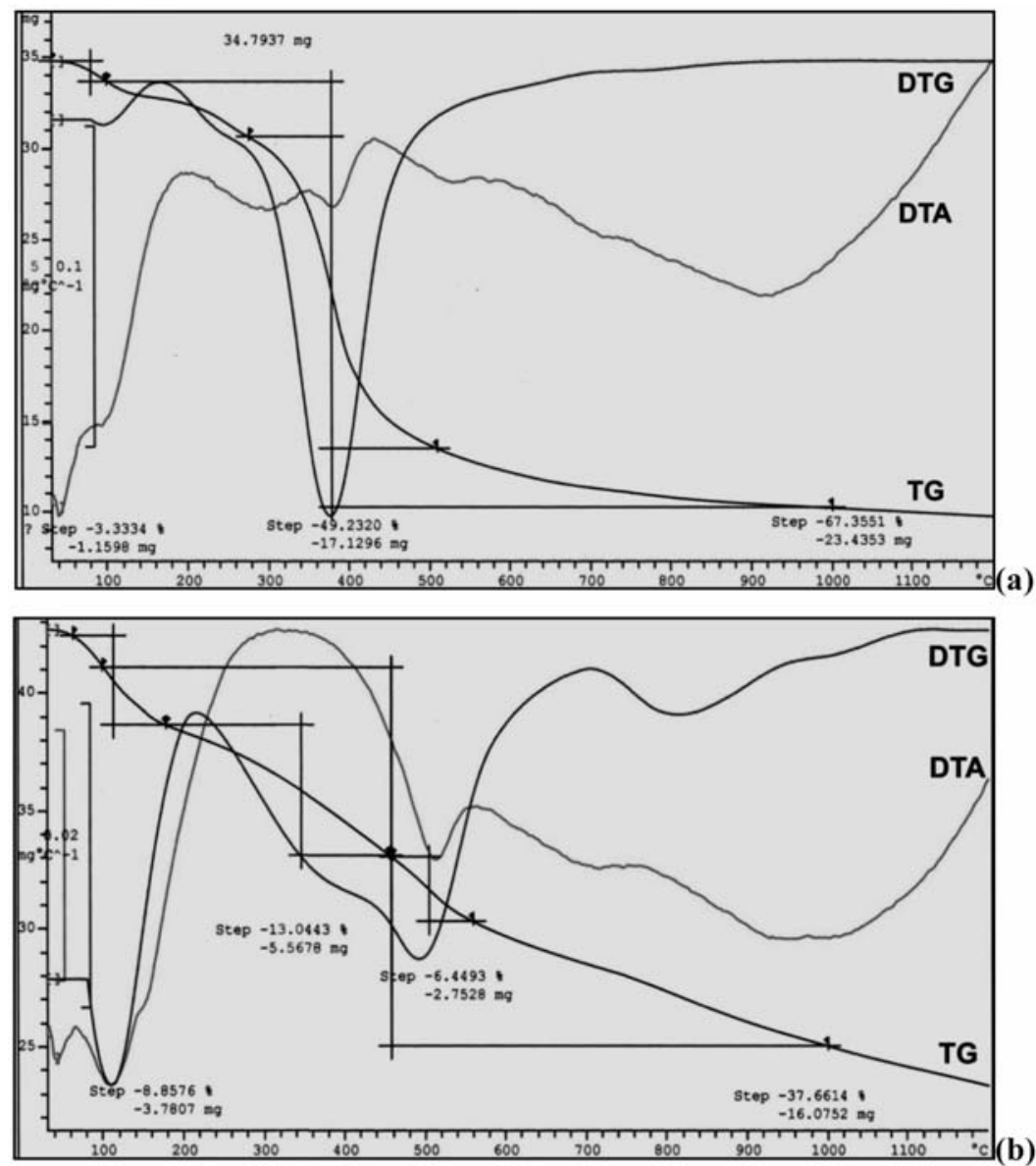

Fig. 4: TG/DTG/DTA diagrams of representative xylite (a) and matrix lignite (b) samples.

- In the temperature range from $200^{\circ} \mathrm{C}$ to $560^{\circ} \mathrm{C}$, the weight loss is less than in xylite sample and this is indicated by the slight slope of the TG curve.

- The TG curve of the matrix lignite samples showed a continuous weight loss during heating up to $\sim 900^{\circ} \mathrm{C}$, originated from the lignin content, that is quite difficult to decompose, as well as from the presence of inorganic material.

- The exothermic peak in the temperature range from $200^{\circ} \mathrm{C}$ to $400^{\circ} \mathrm{C}$ of DTA curve is characteristic of lignin and can be attributed to the destruction of aliphatic grouping, $\mathrm{CH}$ groups, carbohydrate components and to some extent of oxygeneous (alcoholic, phenolic) and amino groups (Kucerik et al., 2004).

- The endothermic peak at $\sim 500^{\circ} \mathrm{C}$ is attributed to the dehydroxylation of the kaolinite, (due to the loss of $\mathrm{OH}$ groups, surrounding the $\mathrm{Al}^{\mathrm{VI}}$ atoms) and the progressive transformation from the octahedral co-ordinated Al, in kaolinite, to a tetrahedral co-ordinated form, in metakaolinite, through the breaking of $\mathrm{OH}$ bonds (Van Jaarsveld et al., 2002). A part of the weight loss in this temperature range comes from the decomposition of siderite according to the reaction 
$\mathrm{FeCO}_{3} \rightarrow \mathrm{FeO}+\mathrm{CO}_{2}$. Chlorite and illite (+muscovite) give endothermic peaks at higher temperatures.

\section{Conclusions}

Studying the xylite and matrix lignite lithotypes from the organic beds of Achlada lignite deposits, Florina sub-basin, NW Greece, by FT-IR spectroscopy, in combination with X-ray diffraction and thermoanalytical methods (TG/DTG and DTA), the following conclusions were taken:

- The FTIR spectra of all samples confirm the progressive elimination of aliphatic vibrations from xylite lithotype to matrix lignite one and the appearance of clay minerals in the latter.

- The aliphatic stretching regions at $3000-2800 \mathrm{~cm}^{-1}$ and $1700-1100 \mathrm{~cm}^{-1}$, where the vibrations of C-H and C-O groups at $\sim 1458 \mathrm{~cm}^{-1}, 1370 \mathrm{~cm}^{-1}, 1267 \mathrm{~cm}^{-1}$ and $1224 \mathrm{~cm}^{-1}$ are present, reduced in matrix lignite.

- The vibrations corresponding to the occurrence of clay minerals $\left(\sim 3697 \mathrm{~cm}^{-1}, 3620 \mathrm{~cm}^{-1}, 1034\right.$ $\mathrm{cm}^{-1}, 915 \mathrm{~cm}^{-1}, 531 \mathrm{~cm}^{-1}, 469 \mathrm{~cm}^{-1}$ and $\left.435 \mathrm{~cm}^{-1}\right)$, are more evident in matrix lignite samples and very weak in xylite ones.

- According to X-ray analysis the minerals present in the matrix lignite are mainly illite (+muscovite), kaolinite, and gypsum, while in the xylite samples these minerals are absent. The formation of anhydrite in the heated samples indicates the presence of gypsum in both raw materials.

- The TG/DTG/DTA curves of xylite lithotype present higher weight loss comparing to matrix lignite lithotype, as well as a sharp DTG peak at $\sim 380^{\circ} \mathrm{C}$, accompanied with an endothermic peak of DTA curve, that is characteristic of cellulose decomposition. In contrast, the lignin decomposition is characterized by an exothermic peak in the temperature range from $200^{\circ} \mathrm{C}$ to $400^{\circ} \mathrm{C}$.

\section{Acknowledgments}

The authors would like to thank D. Tsiakalos and S. Papadakis for their staunch support during the laboratory work, as well as both the mining engineers Th. Balis and O. Grammenopoulos of the Achlada lignite mine for their support during the sampling.

\section{References}

Balan, E., Marco Saita, A., Mauri, F., and Calas, G., 2001. First-principles modeling of the infrared spectrum of kaolinite. Americal Mineralogist, 86, 1321-1330.

Charland, J.-P., MacPhee, J.A., Girou, L., Price, J.T., Khan, M.A., 2003. Application of TG-FTIR to the determination of oxygen content of coals. Fuel Processing Technology, 81, 211-221.

Cloke, M., Gilfillan, A., and Lester. E., 1997. The characterization of coals and density separated coal fractions using FTIR and manual and automated petrographic analysis. Fuel, 76(13), 1289-1296.

D'Alessio, A., Vergamini, P., Benedetti, E., 2000. FT-IR investigation of the structural changes of Sulcis and South Africa coals under progressive heating in vacuum. Fuel, 79, 1215-1220.

Das, T.K., 2001. Thermogravimetric characterization of maceral concentrates of Russian coking coals. Fuel, 80, 97-106.

Geng, W., Nakajima, T., Takanashi, H., Ohki, A., 2009. Analysis of carboxyl group in coal and coal aromaticity by Fourier transform infrared (FT-IR) spectrometry. Fuel, 88, 139-144. 
Georgakopoulos, A., Iordanidis, A., and Karma, V., 2003. Study of Low Rank Coals Using FTIR Spectroscopy. Energy Sources, 25, 995-1005.

Guiliano, M., G. Mille, P. Doumenq, Kister, J., and Muller, J.F., 1990. Study of various rank demineralised coals and maceral concentrates: Band assignment of FTIR spectra after resolution enhancement using Fourier deconvolutions. In H. Charcosset (eds), Advanced Methodologies in Coal Characterization, Coal Science and Technology, 15, pp. 399-417, Amsterdam, Elsevier.

Ibarra, J.V., Munoz, E., and Moliner, R., 1996. FTIR study of the evolution of coal structure during the coalification process. Org. Geochem, 24, 725-735.

International Committee for Coal and Organic Petrology (ICCP), 1993. International Handbook of Coal Petrography. Supplement, Commision 1, 19 pp.

Kalaitzidis, S., 2007. Peat-forming and evolution of peatlands in Greece. Phd Thesis, University of Patras, $350 \mathrm{p}$.

Killops, S.D. and Killops, V.J., 1993. An introduction to organic geochemistry. New York, Longman, 265 p.

Koch, A., Krzton, A., Finqueneisel, G., Heintz, O., Weber, J., and Zimny, T., 1998. A study of carbonaceous char oxidation in air by semi-quantitative FTIR spectroscopy. Fuel, 77(6), 563-569.

Kucerík, J., Kovár, J., Pekar, M., 2004. Thermoanalytical investigation of lignite humic acids fractions. J. Thermal Analysis Calorimetry, 76(1), 55-65.

Lide, D.R., 1991. CRC Handbook of Chemistry and Physics. Boston: CRC Press.

MacPhee, J.A., Giroux, L., Charland, J.-P., Gransden, J.F., Price, J.T., 2004. Detection of natural oxidation of coking coal by TG-FTIR-mechanistic implications. Fuel, 83, 1855-1860.

Madejova, J., 2002. FTIR techniques in clay mineral studies. Vibrational Spectroscopy, 944, 1-10.

Madejová, J., 2003. FTIR techniques in clay mineral studies. Vibrational Spectroscopy, 31(1), 1-10.

Mastalerz, M. and Bustin, R.M., 1995. Application of reflectance micro-Fourier transform infrared spectrometry in studying coal macerals: comparison with other Fourier transform infrared techniques. Fuel, 74(4), 536-542.

Mastalerz, M. and Bustin, R.M., 1996. Application of reflectance micro-Fourier Transform infrared analysis to the study of coal macerals: an example from the Late Jurassic to Early Cretaceous coals of the Mist Mountain Formation, British Columbia, Canada. Int. J. Coal Geol., 32, 55-67.

Pavlides, S. and Mountrakis, D., 1987. Extensional tectonics of northwestern Macedonia,Greece, since the late Miocene. J. Struct. Geol., 9/4, 385-395.

Sobkowiak, M. and Painter, P., 1992. Determination of the aliphatic and aromatic CH contents of coals by FT-IR: studies of coal extracts. Fuel, 71(10), 1105-1125.

Taylor, G.H., Teichmuller, M., Davis, A., Diessel, C.F.K., Littke, R., and Robert, P., 1998. Organic Petrology. Gebruder Borntraeger, Berlin and Stuttgart, 704 p.

Vamvuka, D., Kastanaki, E., Lasithiotakis, M., Papanicolaou C., 2004. Combustion behavior of xylite/lignite mixtures. Carbon, 42, 351-359.

Van Jaarsveld, J., Van Deventer, J., Lukey, G., 2002. The effect of composition and termperature on the properties of fly ash and kaolinite-based geopolymers. Chemical Engineering J., 89, 63-73.

Van Krevelen, D.W., 1993. Coal. Typology - Physics - Chemistry - Constitution, (3rd ed.). Amsterdam, Elsevier, 979 p.

Wang, S.H. and Griffiths, P.R. 1985. Resolution enhancement of diffuse reflectance IR spectra of coals by Fourier self -deconvolution 1. C-H stretching and bending modes. Fuel, 64, 229-236. 